\title{
イネ穂枯れに関する調査
}

\author{
滝 川 憲 嗣*
}

\section{Investigation on the Rice Ear Blighting in Nara Prefecture}

\section{Kenji Takigawa}

摘要 : 近年イネの成熟期ごろになって穂色が污ない, いわゆる穂枯れ症状の被州が目立つことがある。奈良 県では西部生駒, 金剛山地域, 南部の吉野川河谷地域 などのいわゆる秋落地帯に発生が多い。東海近畿地域 内での連絡試験として，1969年．1970年の 2 か年間に 本症状を発生させる主病原菌についてその種類調查, ならびに葉身のごま葉枯病と穂枯れとの関係調査をお こなったが，その結果の概要は次のとおりであった。

1. 本県の穂枯れ症状の多く認められる地域は, 西 北部奈良盆地丘陵，生駒金剛山地域，および吉野川河 谷地域の秋落地域に，年次による差はあるが，一般に 他の地域より多くの発生が認められ, その他の地域で も局地的に発生をみることがある.

2. 穂枯れ症状の変色穂から検出される菌種につい
ては, 穂首部, 枝梗部ともに Cladosporium, Helminthosporium, Fusarium, Alternaria などの菌が検出さ れたが,いずれもこれらの数種の混合感染によるもの が多かった。

3.ごま葉枯病の多発田で採取した穂首部からの検 出菌は Helminthosporium が圧倒的に多く, 少発田か らの変色穂からは Cladosporium の検出率が高いよう であったままた，年次によっては主病原菌の変動がみ られるようであった。

4. 各葉位別にみられるごま葉枯病の発生程度と穂 の各部位に执ける罹病率との関係については, 本調査 結果では明確な関係はみられなかったが，ごま葉枯病 の多発する圂場では, 第 3 葉位の多発が枝梗部の発病 にある程度関与しているように推察された．

\section{I .はじめに}

イネの穂枯れに関する研究は, 北陸農試をはじめそ の他の研究機関で多くの研究者によりなされているが, 本県でも近年これら変色穂が問題になりつつある，し かし，いままで本症状により穂首いもち病ほどの著し い被害をうけたことはなく, 秋落地域では年次により 多少の被害を生じることはあったが栽培者には割合安 易に考えられてきたようであった．

穂枯れ症状の主因をなす病原菌として，木谷 ${ }^{2} ら$ らは ごま葉枯病菌によるところが大きいとし，また多くの 研究結果でも同様の報告がなされている. 本県でも, 例年ごま葉枯病の発生する地域で変色穂が概して多く 目立つようであるので, その実態を解明し, 本症状の 主因を明らかにするため調查を実施（東海近畿地域連 絡試験）した. 以下その結果の概要を報告する.

\section{II．穂枯れに関与する病原菌の種類調査}

A. 材料㧍よび方法

県下 5 か所のごま葉枯病の多発生國および少発生围 場から変色穂をそれぞれ50荎採集し，下記方法により 調査を抗こなった。

材料の採集地

奈良盆地縁辺丘陵地域生駒市東山. 北条

生駒山地山簏部地域生駒市平群

金剛山地南部山麓部地域 御所市鴨神

吉野川河谷上部地域吉野郡下市町

奈良盆地平坦部地域高田市有井

上記採集地から採集した病穂を部位別に $3 \mathrm{~cm}$ の長 さに切断してフラスコに入れ, 水とともに手で30回強 く振蕰し, 水洗し, さらに同様の方法で表面の洗浄を 5 回反覆したのち湿室内に並べ, $25^{\circ} \mathrm{C} \sim 26^{\circ} \mathrm{C}$ の定温

* 奈良県農業試験場 
器に48時間保置し, 材料の表面に発生した菌を直接検 鏡し，同定した（北陸農試法，1969）.

\section{B . 調査結果}

1969年および1970年に各地域のごま葉枯病の多発生 围場および少発生甬場から採集した病穂の各部位別検 出菌は，第 1 表〜第 6 表に示すとおりであった.

各採集地から採集した病穗の各部位から検出される
菌種については多くの研究報告がなされているが, 本 県のごま葉枯病発生地域の変色穂からの検出菌につい ては, 穂首部位から Helminthosporium および Cladosporium が多く検出されたこの結果は多くの報告例 と同様であったが，本県の場合この 2 種の混合感染が 最も多いようであった．また，1968年からの奨励品種 の変遷などによりいもち病の発生が目立つ傾向にあり,

第1表 穂首からの検出菌（1969）

\begin{tabular}{|c|c|c|c|c|c|c|c|c|c|c|c|c|}
\hline \multirow{2}{*}{ 採 集 地 名 } & \multicolumn{6}{|c|}{ ごま葉枯病多発生自 } & \multicolumn{6}{|c|}{ ごま葉枯病少発生甬 } \\
\hline & Hel. & Clad. & Pyri. & Alt. & Fus. & 無検出 & Hel. & Clad. & Pyri. & Alt. & Fus. & 無検出 \\
\hline 生駒市平群町 & $\begin{array}{l}\% \\
6\end{array}$ & $\begin{array}{c}\% \\
70\end{array}$ & $\begin{array}{l}\% \\
0\end{array}$ & $\begin{array}{l}\% \\
2\end{array}$ & $\begin{array}{c}\% \\
20\end{array}$ & $\begin{array}{l}\% \\
2\end{array}$ & $\begin{array}{l}\% \\
0\end{array}$ & $\begin{array}{c}\% \\
78\end{array}$ & $\begin{array}{l}\% \\
0\end{array}$ & $\begin{array}{l}\% \\
0\end{array}$ & $\begin{array}{c}\% \\
22\end{array}$ & $\begin{array}{l}\% \\
0\end{array}$ \\
\hline 御所市小殿 & 16 & 91 & 0 & 4 & 27 & 11 & 0 & 73 & 0 & 5 & 27 & 0 \\
\hline 高田市有井 & 13 & 50 & 0 & 77 & 77 & 20 & 8 & 80 & 0 & 38 & 44 & 0 \\
\hline 生駒市東山 & 0 & 80 & 0 & 6 & 14 & 0 & - & - & - & - & - & - \\
\hline
\end{tabular}

第 2 表 穂首からの検出菌 (1970)

\begin{tabular}{|c|c|c|c|c|c|c|c|c|c|c|c|c|}
\hline \multirow{2}{*}{ 採 集 地 名 } & \multicolumn{6}{|c|}{ ごま葉枯病多発生畕 } & \multicolumn{6}{|c|}{ ごま葉枯病少発生婳 } \\
\hline & Hel. & Glad. & Pyri. & Alt. & Fus. & 無検出 & Hel. & Clad. & Pyri. & Alt. & Fus. & 無検出 \\
\hline 生駒市北条 & $\begin{array}{l}\% \\
48\end{array}$ & $\begin{array}{l}\% \\
30\end{array}$ & $\begin{array}{l}\% \\
10\end{array}$ & $\begin{array}{l}\% \\
2\end{array}$ & $\begin{array}{l}\% \\
0\end{array}$ & $\begin{array}{l}\% \\
2\end{array}$ & $\begin{array}{l}\% \\
2\end{array}$ & $\begin{array}{c}\% \\
74\end{array}$ & $\%$ & $\begin{array}{l}\% \\
0\end{array}$ & $\begin{array}{l}\% \\
4\end{array}$ & $\begin{array}{l}\% \\
6\end{array}$ \\
\hline 御所市鴨神 & 46 & 28 & 10 & 2 & 10 & 2 & 一 & - & 一 & - - & - & - \\
\hline 吉野郡大淀町 & 28 & 72 & 2 & 0 & 22 & 18 & 20 & 70 & 4 & 0 & 8 & 10 \\
\hline " 下市町 & 42 & 38 & 2 & 2 & 8 & 28 & 22 & 64 & 8 & 0 & 22 & 4 \\
\hline 桜井市初瀬 & 58 & 36 & 4 & 0 & 8 & 8 & 36 & 44 & 0 & 0 & 6 & 6 \\
\hline
\end{tabular}

第 3 表 枝梗 からの検出菌（1969）

\begin{tabular}{|c|c|c|c|c|c|c|c|c|c|c|c|c|}
\hline \multirow{2}{*}{ 採 集 地 名 } & \multicolumn{6}{|c|}{ ごま葉枯病多発生㘣 } & \multicolumn{6}{|c|}{ ごま葉枯病少発生画 } \\
\hline & Hel. & Clad. & Pyri. & Alt. & Fus. & 無検出 & Hel. & Clad. & Pyri. & Alt. & Fus. & 無検出 \\
\hline 生駒市平群町 & $\begin{array}{l}\% \\
6\end{array}$ & $\begin{array}{c}\% \\
70\end{array}$ & $\begin{array}{l}\% \\
0\end{array}$ & $\begin{array}{l}\% \\
2\end{array}$ & $\begin{array}{c}\% \\
20\end{array}$ & $\begin{array}{l}\% \\
2\end{array}$ & $\begin{array}{l}\% \\
0\end{array}$ & $\begin{array}{c}\% \\
78\end{array}$ & $\begin{array}{l}\% \\
0\end{array}$ & $\begin{array}{l}\% \\
0\end{array}$ & $\begin{array}{c}\% \\
22\end{array}$ & $\begin{array}{l}\% \\
0\end{array}$ \\
\hline 御所市小殿 & 27 & 55 & 0 & 4 & 50 & 18 & 2 & 68 & 0 & 20 & 11 & 16 \\
\hline 高田市有井 & 13 & 20 & 0 & 96 & 77 & 7 & 26 & 48 & 0 & 30 & 44 & 2 \\
\hline 生駒市東山 & 14 & 66 & 0 & 10 & 14 & 12 & - & - & - & - & - & - \\
\hline
\end{tabular}

第4表 枝梗からの検出菌（1970）

\begin{tabular}{|c|c|c|c|c|c|c|c|c|c|c|c|c|}
\hline \multirow{2}{*}{ 採 集 地 名 } & \multicolumn{6}{|c|}{ ごま葉枯病多発生㘣 } & \multicolumn{6}{|c|}{ ごま葉枯病少発生眮 } \\
\hline & Hel. & Clad. & Pyri. & Alt. & Fus. & 無検出 & Hel. & Clad. & Pyri. & Alt. & Fus. & 無検出 \\
\hline 生駒市北各 & $\%$ & $\%$ & $\%$ & $\%$ & $\%$ & $\%$ & $\%$ & $\%$ & $\%$ & $\%$ & $\%$ & $\%$ \\
\hline 御所市鴨神 & 84 & 18 & 2 & 0 & 10 & 10 & - & - & - & - & - & - \\
\hline 吉野群大淀町 & 72 & 10 & 14 & 2 & 4 & 14 & 24 & 60 & 4 & 0 & 8 & 14 \\
\hline " 下市町 & 78 & 2 & 2 & 2 & 24 & 1 & 60 & 20 & 10 & 0 & 16 & 1 \\
\hline 桜井市初瀬 & 90 & 2 & 0 & 0 & 12 & 0 & 58 & 2 & 2 & 2 & 10 & 0 \\
\hline
\end{tabular}


第 5 表 粐からの検出菌（1970）

\begin{tabular}{|c|c|c|c|c|c|c|c|c|c|c|c|c|}
\hline \multirow{2}{*}{ 採 集 地 名 } & \multicolumn{6}{|c|}{ ごま葉枯病多発生㬂 } & \multicolumn{6}{|c|}{ ごま葉枯病少発生眓 } \\
\hline & $\mathrm{Hel}$. & Clad. & Pyri. & Alt. & Fus. & 無検出 & Hel. & Clad. & Pyri. & Alt. & Fus. & 無検出 \\
\hline 生駒市北条 & $\begin{array}{l}\% \\
88\end{array}$ & $\begin{array}{c}\% \\
18\end{array}$ & $\begin{array}{l}\% \\
0\end{array}$ & $\begin{array}{l}\% \\
4\end{array}$ & $\begin{array}{l}\% \\
4\end{array}$ & $\begin{array}{l}\% \\
4\end{array}$ & $\begin{array}{c}\% \\
80\end{array}$ & $\begin{array}{l}\% \\
5\end{array}$ & $\begin{array}{l}\% \\
5\end{array}$ & $\begin{array}{l}\% \\
0\end{array}$ & $\begin{array}{l}\% \\
5\end{array}$ & $\begin{array}{l}\% \\
20\end{array}$ \\
\hline 吉野郡大淀町 & 60 & 16 & 0 & 8 & 12 & 10 & 87 & 3 & 0 & 3 & 7 & 47 \\
\hline " 下市町 & 68 & 24 & 0 & 8 & 16 & 2 & 60 & 10 & 0 & 5 & 15 & 30 \\
\hline 御所市鴨神 & 38 & 14 & 0 & 18 & 26 & 14 & - & - & 一 & 一 & - & - \\
\hline 桜井市初瀬 & 46 & 5 & 0 & 2 & 1 & 3 & 23 & 13 & 0 & 0 & 20 & 47 \\
\hline
\end{tabular}

第 6 表 金剛山地 ごま葉枯病多発生團の穗 首からの検出菌（御所市小殿）

\begin{tabular}{ccc}
\hline 検 出 菌 種 & 1969 & 1970 \\
\hline Helminthosporium oryzae & $16^{\%}$ & $46^{\%}$ \\
Cladosporium sp. & 91 & 28 \\
Pyricularia oryzae & 0 & 10 \\
Alternaria sp. & 4 & 2 \\
Fusarium sp. & 27 & 10 \\
無 検 出 & 11 & 2 \\
\hline
\end{tabular}

1970年には例年ほとんどいもち病の発生のみられなか った本調查地域でも, 変色穂から Pyricularia oryzae が多く検出された.

ごま葉枯病の多発生地域は本県の中山間地域と吉野 川河谷地域とに広く分布するが，これらの地域におけ るごま葉枯病の少発生目から採集した変色穂からの検 出菌は，多発生甬にみられるのとは異なり，Cladosporium sp. および Pyricularia oryzae が穗首部位から 最も多く検出されるようであった．枝梗部からの検出 菌率では Helminthosporium oryzae が多く検出され, 粐部位からは枝梗部同様 Helminthosporium oryzae が 最も多く, 次いで Cladosporium sp. で, 他の菌種との 混合感染による被害もかなり認められた。なお，生駒 金剛山地域の一部ごま葉枯病多発生囬から採取した穂 首からの検出率は, 第 6 表に示したように, 年次によ り検出菌の変動がみられるようであった．

G. 考 察

穂枯れの菌種に関する報告は多いが，それらの研究 結果では主因をなす病原菌として，Helminthosporium oryzae の検出率がいずれも高い. 本県の常発地域では, 1969年はごま葉枯病が比較的少発生であったためか, Helminthosporium oryzae の検出率が低かったが, 1970 年にはごま葉枯病の発生がやや多目で, 変色穂からの Helminthosporium oryzae の検出率も高かった，加えて 同年はいもち病の発生が広域にみられ，地域によって
は変色穗から Pyricularia oryzae が多少検出されてお りまた Helminthosporium oryzae, Cladosporium sp. などとの混合感染による変色穂がかなり多く認められ た.

穂枯れの主因をなす病原菌の検出率が年次により変

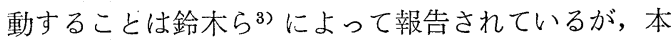
県でも1969〜1970年に，生駒金剛山地域の一部ごま葉 枯病多発地域での調查で同様の傾向が認められた。

また，鈴木ら ${ }^{3)}$ および内海4) は小粒菌核病菌が穂枯 れに関与すると報告しているが，本県での調査対象圊 場の罹病穂からは同菌は検出できなかった。

以上の調査結果から，本県の秋落地域に発生する変 色穂は，そのほとんどが Helminthosporium oryzae， Cladosporium sp. またはそれらと他の病原菌との混合 感染によるものであることが明らかとなったが，さら に地域を变えて広域な調査を行なう必要がある。

なお，本調査は同一甬場での継続調査を行なう予定 であったが，生駒金剛山地域では土壤の改良策がほど こされたため前年発生の多かった画場でも全く発生が 認められず，同一圊場での調査を行なうことはできな かった。

\section{III. 穂枯れの発生程度と葉身におけるご ま葉枯病の発生との関係について}

穂枯れに関与する病原菌の種類が, Helminthosporium oryzae，および Cladosporium sp. によるものが最多で， これらと他の菌との混合感染によるものが多いと判明 したが，穂における本症状が葉の病斑数の多少とどの ような関係があるかを知る目的で本調査を行なった。 調査対象圆場は菌の種類調査を行なったのと同じ薯場 とした。
A. 調查方法
1. 葉におけるごま葉枯病病斑調查
ごま葉枯病病斑調査は, 多発生埇および少発生圊に ついてれぞれ任意に 10 株を選び，各株の 3 茎当りの 
止葉, 次葉, および第 3 葉の葉身の中央部 $5 \mathrm{~cm}$ 内, または葉身当りの病斑数を, 乳熟期 (9月 3 日), 収 穫期（10月 2 日）の 2 回調査した.

\section{2. 穂枯れ罹病穂調査}

上記の各甬場から任意10株の各株 1 茥, 計10茎につ いて, 病穂, 病枝梗の発生率を調査した。

B. 調查結果

本調査は，ごま葉枯病の多発生㘣と少発生直とにお ける各葉位別病斑数と, 穂の各部位別の発生率とを調 査した．まず各葉位別の病斑数についてみると，乳熟 期の調査では，ごま葉枯病多発生甬では特に第 3 葉位 での病斑数がいずれの地域でも多く，上葉位にかけて 少なくなる傾向が顕著であったが，少発生苚場ではほ とんど発病のみられない地域もあった。

\section{第 7 表 乳熟期におけるごま葉枯病病斑} 数調査 (1970)

\begin{tabular}{|c|c|c|c|c|c|c|}
\hline \multirow{3}{*}{ 調査地名 } & \multicolumn{6}{|c|}{ 一葉当り平均病斑数 } \\
\hline & \multicolumn{3}{|c|}{ 多 発 生 顳 } & \multicolumn{3}{|c|}{ 少 発 生 圊 } \\
\hline & 止葉 & 次葉 & 3 葉 & 止葉 & 次葉 & 3 葉 \\
\hline 生駒市北条 & 38 & 57 & 80 & 3 & 5 & 9 \\
\hline 御所市鴨神 & 6 & 12 & 30 & 2 & 3 & 7 \\
\hline 吉野郡大淀町 & 13 & 22 & 50 & 1 & 1 & 6 \\
\hline " 下市町 & 15 & 14 & 29 & 0 & 0 & 0 \\
\hline
\end{tabular}

また収穫期の調査では, イネの生体の老化現象によ る病勢の急激な進展にともない病斑数が急増したため, 葉身 $5 \mathrm{~cm}$ 内の病斑数を調査したが, 特に生駒, 桜井 両地域の多発生嘎ではかなりの発生が認められ, 第 3 葉位での枯死葉が目立った。同時期に行なった穗首各 部位における発病率調査では, 枝梗部での発病率が最 も高く, 次いで穂首部となっており,この傾向は各地 域とも同様であった。

病穂首率，病枝梗率と葉の病斑数との関係について は，本調查結果からは明確な結果を得ることはできな かったが, 葉の病斑数の多少が枝梗部の発病率にある 程度関連しているのではないかと考えられる。

\section{G. 考察}

以上の結果では葉の罹病状況と穂斑れの発病との関 係については明確な結論がえられなかったが，これに は調査対象围の筆数が少なかったことと，また，地域 の耕種条件や地力差などがかなり影響しているものと 考えられた.

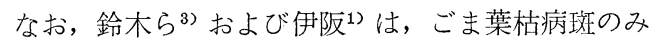
られない地域においても, ときには穂枯れの多発を認
第 8 表 収穫期におけるごま葉枯病病斑 数調查 (1969)

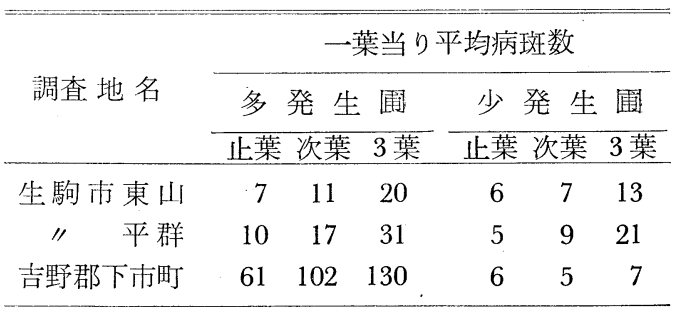

第 9 表 収穫期における病穂調査（1969）

\begin{tabular}{|c|c|c|c|c|c|c|}
\hline \multirow{3}{*}{ 調査地名 } & \multicolumn{2}{|r|}{ 発 } & 病 & \multicolumn{3}{|c|}{ 率 $(\%)$} \\
\hline & \multicolumn{3}{|c|}{ 多 発 生 䁬 } & \multicolumn{3}{|c|}{ 少 発 生 圊 } \\
\hline & 穂首 & 枝梗 & 粐 & 穂首 & 枝梗 & 粐 \\
\hline 生駒市東山 & 47 & 100 & 83 & 43 & 69 & 37 \\
\hline 平群 & 30 & 97 & 31 & 22 & 79 & 21 \\
\hline 吉野郡下市町 & 67 & 90 & 60 & 23 & 77 & 45 \\
\hline
\end{tabular}

第10表 収穫期におけるごま葉枯病斑数（1970）

\begin{tabular}{|c|c|c|c|c|c|c|}
\hline \multirow{3}{*}{ 調査地名 } & \multicolumn{6}{|c|}{ 葉身 (5 cm内) 平均病斑数 } \\
\hline & \multicolumn{3}{|c|}{ 多 発 生 期 } & \multicolumn{3}{|c|}{ 少 発 生 甬 } \\
\hline & 止葉 & 次葉 & 3 葉 & 止葉 & 次葉 & 3 葉 \\
\hline 生駒市北条 & 42 & 52 & 61 & 7 & 8 & 13 \\
\hline 御所市鴨神 & 11 & 18 & 11 & 3 & 3 & 2 \\
\hline 吉野郡大淀町 & 15 & 11 & 28 & 13 & 17 & 25 \\
\hline " 下市町 & 16 & 16 & 17 & 2 & 2 & 2 \\
\hline 桜井市初瀬町 & 38 & 41 & 100 & 13 & 10 & 100 \\
\hline
\end{tabular}

第11表 収穫期における病穂調査（1970）

\begin{tabular}{|c|c|c|c|c|c|c|}
\hline \multirow{3}{*}{ 調査地名 } & \multicolumn{2}{|r|}{ 発 } & 病 & \multicolumn{3}{|c|}{ 率 $(\%)$} \\
\hline & 多 & 発 生 & 直 & 少 & 発 生 & 固 \\
\hline & 穂首 & 枝梗 & 粐 & 穗首 & 枝梗 & 粐 \\
\hline 生駒市北条 & 21 & 41 & 36 & 18 & 39 & 28 \\
\hline 御所市鴨神 & 28 & 44 & 44 & 一 & 一 & 一 \\
\hline 吉野郡大淀町 & 40 & 56 & 37 & 8 & 29 & 28 \\
\hline " 下市町 & 48 & 83 & 29 & 18 & 36 & 57 \\
\hline 桜井市初瀬 & 36 & 50 & 17 & 21 & 48 & 8 \\
\hline
\end{tabular}

めることがあると述べている，このことについては， 践畔雑草のマコモ, サヤ文カグサなどから Helminthosporium が分離されることが多いことから，これら雑 草が伝染源となりうると報告されている。

奈良県でも近年平坦部にも穂枯れが多くみられるよ うになってきたが，これらの地域では強度の秋落現象 もなく，またごま葉枯病の発生も極めて少ない睓場で 
ある，従来平坦部ではいもち病の発生はほとんど問題 にならなかった。したがって, いもち病を対象とした 薬剂防除は抗こなわれない現状にあり，また混合農薬 による散布適期のずれなどのために穂枯れの病原菌に 対する薬剤効果も十分発揮されないことなどが，本症 状の漸増を助長しているものと考えられる。また，転 作, 休耕田などの畦畔雑草からの伝染も考えられるの でささらにこれらの要因についても明らかにしておく 必要がある。

\section{引用 文 献}

1）伊阪実人（1961）：北陸病虫研報 9，34-38.

2）木谷清美 - 大畑貫一 - 久保千冬（1970）：四国農 試報告 $22 ， 27-117$.

3）鈴木穂積・山口富夫（1972）：北陸農試報告 14, $63-83$.

4）内海 繁 $(1951-52)$ ：新潟農試速報 $10 ， 5-$ $8 ; 13,11-14$,

\section{Summary}

The species of causal fungi of rice ear blighting and the relationship between ear blighting and Helminthosporium leaf spot were investigated in Nara Prefecture for two years extending from 1969 to 1970 . The results are summarized as follows.

1. The rice ear blighting was found to be prevalent in the hilly regions northwest of Nara-City, in the regions around Mt. Ikoma and Mt. Kongo, and in the "akiochi" regions along the riversides of Yoshino. The outbreak of ear blighting in these regions was generally more frequent than in the others, though local outbreak may occasionally be observed in the latter.

2. The fungi detected from the neck of diseased ears were Cladosporium, Helminthosporium, Fusarium, Alternaria, etc. Ear blighting in most cases was likely the symptom of the mixed infection with these fungi.

3. Helminthosporium was detected with high frequency from the necks of diseased ears collected from the fields where Helminthosporium leaf spot was prevalent, while Cladosporium was frequently found on the samples from the fields with less incidence of Helminthosporium leaf spot. The species of major causal fungi may sometimes be varied year by year.

4. Any significant correlation was hardly found between the severity of Helminthosporium leaf spot and that of ear blighting. In the fields, however, where Helminthosporium leaf spot was prevalent, the heavy incidence of the leaf spots on the 3rd leaf from the top was presumed to be somewhat related to the infection of panicle branches. 